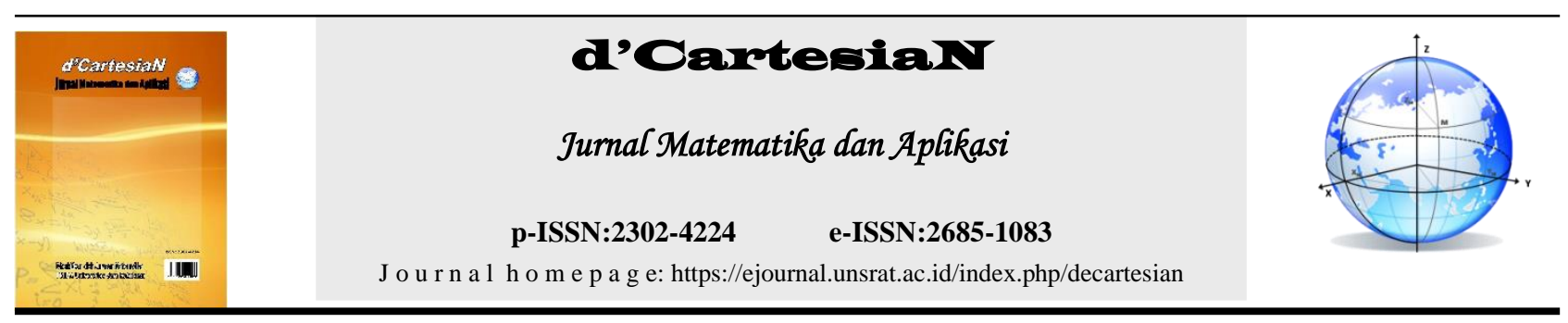

\title{
Analisis Kepuasan Pasien Di RSUD Teep Amurang Dengan Menggunakaan Metode Multivariate
}

\author{
Liani Somba', Nelson Nainggolan', Hanny A.H. Komalig ${ }^{1^{*}}$ \\ ${ }^{1}$ Jurusan Matematika-Fakultas Matematika dan Ilmu Pengetahuan Alam-Universitas Sam Ratulangi Manado, Indonesia
}

*Corressponding author : hanoyo7@yahoo.com

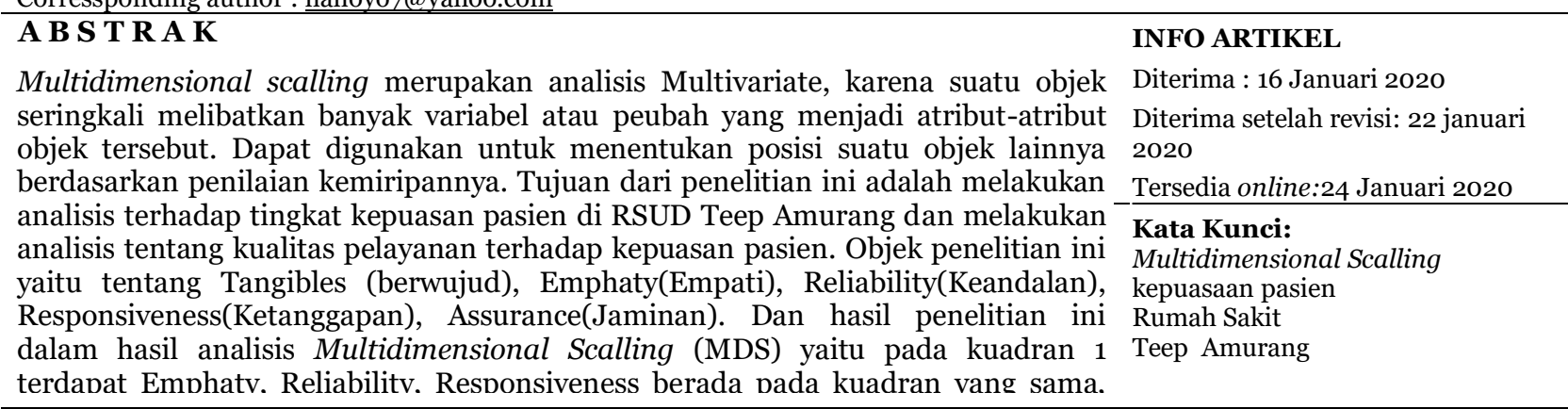

\section{A B S T R A C T}

Multidimensional Scalling is a multivariate analysis, because an object often involves many variables or variables that become attributes of the object. Can be used to determine the position of another object based on an assessment of this similarity. The purpose of this study is to analyze the level of patient satisfaction at the Teep Amurang Hospital and conduct an analysis of the quality of service to patient satisfaction. The object of this research is about Tangibles, Emphaty, Reliability, Responsiveness, Assurance. And the results of this study in the analysis of Multidimensional Scalling that is in quadran one there are emphaty, reliability,

\section{ARTICLE INFO}

Accepted : 16 January 2020

Accepted after revision: 22 January 2020

Available online : 25 January 2020

\section{Keywords:}

Multidimensional Scalling

Patient Satisfaction

Hospital

Teep Amurang

\section{PENDAHULUAN}

Rumah Sakit merupakan salah satu penyelenggara pelayanan kesehatan penting bagi masyarakat. Dalam pelayanan tersebut diperlukan hubungan timbal balik antara petugas rumah sakit dengan pasien, sehingga tercipta kualitas pelayanan yang baik. Penelitian ini bertujuan mengukur tingkat kualitas pelayanan dan kepuasan pasien di beberapa rumah sakit yang berada di Sulawesi Utara dengan metode Importance Performance Analysis (IPA) dan beberapa metode multivariat. Teknik pengambilan sampel secara cluster random dengan purposive sampling yang sesuai dengan kriteria penelitian. Data dianalisa secara matriks IPA, analisis regresi logistik dan deskripsi multivariat. Target yang akan dicapai yaitu mengetahui tingkat kepuasan pasien terhadap setiap pernyataan dengan uji gap, mengetahui rata-rata dari tingkat kepuasan dan tingkat kinerja sehingga bisa diketahui pelayanan yang baik serta yang perlu perbaikan dengan uji Cartesian. Hal ini akan memberikan kontribusi yang baik kepada rumah sakit sebagai standar penilaian kepuasan dalam pelayanan kepada pasien. Topik penelitian ini sejalan dengan Rencana Induk Penelitian (RIP) Unsrat tentang pengembangan teknologi kesehatan dan obat-obatan dengan berkontribusi dalam mengembangkan akses pelayanan kesehatan bagi masyarakat.
RSUD Teep Amurang adalah salah satu layanan kesehatan milik pemkab Minahasa Selatan yang terbentuk RSU dilurus oleh RSUD Amurang negeri yang tergolong kedalam RS kelas belum ditetapkan. Layanan kesehatan ini telah teregistrasi semenjak 14/04/2015 dengan nomor surat izin 188.4/SKDINKES/2084/V/2014 dan tanggal surat izin 28/05/2013 dari Dinkes Provinsi Sulut dengan sifat Perpanjang dan berlaku sampai 1 tahun. RSUD ini berlokasi di Desa Teep jl.trans Sulawesi, Minahasa Selatan. RSUD ini mempunyai layanan unggulan dalam bagian. Rumah sakit ini merupakan Rumah Sakit dengan kelas Non-K.

Ada lima (5) dimensi kualitas pelayanan, antara lain : reliability (kehandalan), responsiveness (ketanggapan), assurance (jaminan kepastian), emphaty (empati/perhatian) dan tangible (wujud nyata). Lima dimensi kualitas pelayanan tersebut digunakan untuk mengukur kepuasan pasien dalam mendapatkan pelayanan kesehatan yang diberikan oleh Rumah Sakit[1].

MDS merupakan salah satu teknik analisis Multivariate, karena suatu objek seringkali melibatkan banyak variabel atau peubah yang menjadi atributatribut objek tersebut. Tujuan MDS adalah untuk menyajikan secara visual hubungan dalam sebuah 
grafik. Kelebihan MDS adalah pengukuran berdasarkan skala data yang akan di olah. MDS juga memiliki beberapa jenis penyelesaian, jenis tersebut dikelompokkan dalam dua kelompok yaiytu metrik dan non-metrik. MDS telah digunakan dalam berbagai bidang. Salah satu bidang yang menggunakan prosedur MDS adalah bidang pemasaran untuk membandingkan posisi relatif suatu objek dengan objek laiinnya berdasarkan persepsi konsumen dan masih bayak lagi penerapan MDS dalam kehidupan sehari-hari.

Metode analisis Multivariat adalah suatu metode statistik yang tujuan digunakannya adalah untuk menganalisis data yang terdiri dari banyak variabel serta diduga antar variabel tersebut saling berhubungan satu sama lain.Analisis Multivariat melibatkan variabel dalam jumlah lebih dari atau sama dengan 3 variabel. Dimana minimal ada satu variabel terikat dan lebih dari satu variabel bebas serta terdapat korelasi atau ketrikatan antara satu variabel dengan Variabel lainnya. Analisis multivariat dapat digunakan untuk mengatasi kehidupan sehari-hari. Seperti mengolompokkan objekobjek yang mempunyai kesamaan karakteristik. Ukuran kesamaan yang digunakan adalah ukuran jarak antar objek.

Metode analisis multivariat adalah suatu metode statistika yang tujuan digunakannya adalah untuk menganalisis data yang terdiri dari banyak variabel serta diduga antar variabel tersebut saling berhubungan satu sama lain. Analisis multivariat adalah salah satu dari teknik statistik yang diterapkan untuk memahami struktur data dalam dimensi tinggi. Dimana variabelvariabel yang dimaksud tersebut saling terkait satu sama lain. Analisis multivariat tidak lepas dari jenis data atau skala data. Skala data yang digunakan ada dua macam yaitu data metrik dan data non metrik. Data metrik terdiri dari dua macam yaitu data interval dan data rasio. Sedangkan data non metrik adalah data non numerik atau disebut juga data kualitatif atau data kategorik.

\section{Metode Mengukur Kepuasan Pasien}

Ada beberapa metode yang digunakan untuk

mengukur kepuasan pasien atau pelanggan antara lain:

1. Sistem keluhan dan saran dengan menyediakan kotak saran, hotline service dan lain-lain untuk memberikan kesempatan seluas-luasnya kepada pasien atau pelanggan untuk menyapaikan keluhan, saran, komentar dan pendapat mereka.

2. Ghost shopping (pembelanja misterius) Metode ini, organisasi pelayanan kesehatan mempekerjakan beberapa orang untuk berperan atau bersikap sebagai pasien/pembeli potensial produk/pelayanan organisasi kesehatan lain yang kemudian melaporkan temuannya sehingga dapat dijadikan pertimbangan dalam pengmbilan keputusan organisasinya.

3. Survei kepuasan pelanggan Untuk mengetahui kepuasan pelanggan para pemasar juga dapat melakukan berbagai penelitian atau survei mengenai kepuasan pelanggan misalnya melalui kuesioner, pos, telepon, ataupun wawancara langsung [2].

Dalam mengukur kepuasan pasien ada 10 indikator. Dalam perkembangan selanjutnya 10 indikator tersebut dirangkum menjadi 5 dimensi mutu pelayanan penentu kualitas yang biasanya disebut Model SERVQUAL (service quality) kemudian banyak dipakai sebagai landasan konsep penelitian tentang kepuasan pasien di banyak tempat. Model ini menyebutkan bahwa pertanyaan mendasar yang cukup sensitif untuk mengukur pengalaman konsumen mendapatkan pelayanan tercakup dalam lima dimensi kualitas pelayanan yaitu [3]:

1. Reliability (kehandalan): kemampuan untuk menampilkan pelayanan yang dijanjikan dengan segera dan akurat.

2. Responsiveness (ketanggapan atau kepedulian): kemampuan untuk membantu konsumen dan meningkatkan kecepatan pelayanan.

3. Assurance (jaminan kepastian): kompetensi yang dimiliki sehingga memberikan rasa aman, bebas dari bahaya, risiko atau keraguan dan kepastian yang mencakup pengetahuan, perilaku dan sifat yang dapat dipercaya.

4. Empathy (perhatian): sifat dan kemampuan untuk memberikan perhatian penuh kepada pasien, kemudahan melakukan kontak dan komunikasi yang baik Tangibles (wujud nyata): penampilan fisik dari fasilitas, peralatan, sarana informasi atau komunikasi dan petugas atau pegawai.

\section{Analisis Multivariat}

Analisis statistik multivariat merupakan metode dalam melakukan penelitian terhadap lebih dari dua variable secara bersamaan. Dengan menggunakan teknik analisis ini maka kita dapat menganalisis pengaruh beberapa variable terhadap variabel lainnya dalam waktu yang bersamaan. Berdasarkan hubungan antar variabel, analisis multivariat dapat dibedakan menjadi dependence techniques dan interdependence techniques. Dalam dependence techniques, terdapat dua jenis variabel, yaitu variabel terikat dan variabel bebas. Dependence techniques ini digunakan untuk menyelesaikan permasalahan-permasalahan mengenai hubungan antara dua kelompok variabel tersebut. Sedangkan dalam interdependence techniques, kedudukan setiap variabel sama, tidak ada variabel terikat dan variabel bebas. Biasanya interdependence techniques ini digunakan untuk melihat saling keterkaitan hubungan antar semua variabel tanpa memperhatikan bentuk variabel yang dilibatkan [4].

a. Teknik Multivariat :

1. Teknik Dependence yaitu untuk menyelesaikan permasalahan-permasalahan mengenai hubungan antara dua kelompok variabel. Bila peneliti dalam analisis multivariate dapat mengenali variabel dependen dan independen, maka teknik ini disebut teknik dependen. Teknik dependen memiliki dua kelompok berdasarkan : a. Jumlah variabel dan,

b. Jenis pengukuran data baik variabel dependen maupun independen.

Berdasarkan jumlah variabel dependen, teknik dependen bisa memiliki satu, dua atau beberapa variabel dependen. Setelah diketahui jumlah variabel dependen, selanjutnya dikelompokan berdasarkan jenis pengukuran data baik variabel dependen maupun independen.

2. Teknik Interpedence yaitu :

a. kedudukan variabel sama tidak ada variabel terikat

b. untuk melihat saling keterkaitan hubungan antara semua variabel tanpa memperhatikan bentuk variabel yang dilibatkan.

Variabel bebas/Independence (X) berjumlah lebih dari satu, sebanyak n. sedangkan variabel tidak bebas/dependence (Y) berjumlah lebih dari satu, 
sebanyak $\mathrm{m}$ dimana jumlah $\mathrm{n}>\mathrm{m}$ jenis variabel bisa Kategorik (nominal dan ordinal ) maupun numerik (interval dan rasio). Tujuan utama analisis Interdependen adalah menganalisis mengapa dan bagaimana variabel yang saling berhubungan. Metode interdependen ditentukan berdasarkan jenis pengukuran variabel apakah bersifat metrik atau non metrik.

Tabel 1. Jenis Analisis Interpedence

\begin{tabular}{|c|l|l|}
\hline No & \multicolumn{1}{|c|}{ Jenis Analisis } & \multicolumn{1}{|c|}{$\begin{array}{c}\text { Jenis } \\
\text { Variabel }\end{array}$} \\
\hline 1 & Analisis Faktor & Metrik \\
\hline 2 & Analisis kluster & Metrik \\
\hline 3 & Analisis Koresponden & Metrik \\
\hline 4 & $\begin{array}{l}\text { Analisis Skala } \\
\text { Multidimensional }\end{array}$ & $\begin{array}{l}\text { Non } \\
\text { Metrik }\end{array}$ \\
\hline
\end{tabular}

\section{Analisis Multidimensional Scalling (MDS)}

Analisis Multidimensional Scalling merupakan salah satu teknik an objek lainnya [5]. analisis yang menyampikan informasi yang berupa tampilan peta atau gambar dua dimensi yang menunjukan posisi relative suatu objek dengpeubah ganda yang dapat digunakan untuk mentukan posisi suatu objek lainnya berdasarkan penilaian kemiripannya. MDS digunakan untuk mengutahui hubungan interdepensi atau saling ketrgantungan antar variabel atau data. Analisis multidimensional scaling (MDS) merupakan salah satu teknik peubah ganda yang dapat digunakan untuk menentukan posisi suatu objek lainya berdasarkan penilaian kemiripannya. MDS berhubungan dengan pembutan map untuk menggambarkan posisi sebuah objek dengan objek lainnya berdasarkan kemiripan objek-objek tersebut.

Multidimensional Scalling kegunaanya untuk menyajikan objek-objek secara visual berdasarkan kemiripan yang dimiliki. Selain itu kegunaan lain dari teknik ini adalah mengolompokkan objek-objek yang dimiliki kemiripan dilihat dari beberapa peubah atau atribut yang dianggap mampu mengelompokkan objekobjek tersebut. Sehingga dapat disimpulkan bahwa, Multidimensional Scalling [6]:

a. Kumpulan teknik-teknik statistika untuk menganalisis kemiripan dan ketakmiripan antara objek.

b. Memberikan hasil yang berupa plot titik-titik sehingga jarak antar titik menggambarkan tingkat kemiripan atau ketakmiripan.

c. Memberikan petunjuk untuk mengidentifikasi atribut tak diketahui atau faktor yang mempengaruhi menculnya kemiripan atau ketakmiripan.

Ukuran yang digunakan dalam mengukur hubungan antara objek ialah proximity yang berarti "kedekatan" objek satu dengan objek lainnya. Misalkan himpunan $n$ objek yanv memiliki ketidakmiripan $\left\{\delta_{r t}\right\}$ dengan $\mathrm{r}, \mathrm{t}=$ $1,2, \ldots, n$. Suatu konfigurasi dari $n$ titik dalam ruang dimensi $p$ mewakili objek-objek yang diamati dengan jarak antar titik dilambangkan dengan $\left\{d_{r t}\right\}$.

\section{Jenis-jenis Multidimensional scalling}

Dalam melakukan analisis MDS menggunakan nilai yang menggambarkan tingkat kemiripan atau ketidakmiripan antara objek yang disebut proximity [7]. Proximity dibedakan berdasarkan skala pengukuran yang digunakan dalam Multidimensional Scalling :
1. Untuk skala pengukuran rasio, proximity adalah gambaran nilai sebenarnya dikalikan dengan sebuah bilangan dan ditambah eror.

2. Untuk skala pengukuran ordinal, proximity adalah gambaran nilai sebenarnya hanya sebagai nilia yang memiliki sifat terurut dan ditambah eror.

3. Skala pengukuran interval, proximity adalah gambaran iniali sebenarnya, mungkin dikalikan dengan suatu bilangan dan ditambah eror.

Proximity dibagi atas dua yaitu similarity (kemiripan) yaitu jika semakin kecil nilai jaraknys, menunjukan bahwa objeknya lebih mirip. Kedua, dissimilarity (ketakmiripan) yaitu jika semakin besar nilai jaraknya, menunjukan bahwa objeknya semakin tak mirip. Keberhasilan dari proses ini ditentukan ole seberapa baik jarak yang dihasilkan $\left(\hat{d}_{i j}\right)$ dalam ruang sesuai dengan proximities yang sebenarnya $\left(\delta_{i j}\right)$.

MDS dibedakan atas MDS berskaka metrik dan MDS berskala non-Metrik. Konsep dasar dari multidimensional scalling adalah jarak yang dihasilkan dalam ruang harus sesuai dengan proximities yang sebenarnya. Sehingga yang dilakukan oleh multidimensional scalling adalah mencari posisi dalam ruang dan koordinat untuk setiap stimuli. Diharapkan jarak yang dihasilkan akan mendekati nilai proximities. MDS dibedakan menjadi :

a. Multidimensional Scalling Metrik

Data jarak yang digunakan dalam Multidimensional Scallingg Metrik adalah data rasio dan interval. Multidimensional Scalling Metrik digunakan untuk menemukan himpunan titik dalam ruang dimensi $n$ dimana masingmasing titik mewakili satu objek sehingga jarak antara titik adalah $d_{r t} \approx f\left(\delta_{r t}\right)$, dimana $f$ adalah fungsi monotonik parametik parametik kontinu. Fungsi ini dapat berupa identitas maupun fungsi transformasi ketidakmiripan menjadi bentuk jarak. Jenis Multidimensional Scalling Metrik yang sering digunakan adalah yang diperkenalkan oleh Young dan Householder pada tahun 1938. Dalam scalling classic ketidakmiripan $\left\{\delta_{r t}\right\}$ diperlakukan sebagai jarak euklid. Koordinat $n$ titik dalam ruang euklid dimensi $p$ adalah $x_{r}(r=1, \ldots, n)$ dimana $x_{r}\left(x_{r 1, \ldots,}, x_{r p}\right)^{T}$. Jarak euklid antara titik ke $r$ dan $t$ adalah [8] :

$$
d_{r t}^{2}=\left(x_{r 1}, \ldots, x_{r p}\right)^{T}\left(x_{r 1}, \ldots, x_{r p}\right)
$$

Misalkan matriks hasil kali dalam B, dimana :

$$
[B]_{r t}=b_{r t}=x_{r}^{T} x_{t}
$$

Misalkan, mencari matriks B dari persamaan (3) diperoleh :

$$
\begin{aligned}
d_{r t}^{2}= & x_{r}^{T} x_{r}+x_{r}^{T} x_{t}-2 x_{r}^{T} x_{t} \\
& \frac{1}{n} \sum_{r}^{n}=1 d_{r t}^{2}=\frac{1}{n} \sum_{r=1}^{n} x_{r}^{T} x_{r}+x_{r}^{T} x_{t} \\
& \frac{1}{n} \sum_{r}^{n}=1 d_{r t}^{2}=x_{r}^{T} x_{t}+\frac{1}{n} \sum_{r=1}^{n} x_{r}^{T} x_{r} \\
& \frac{1}{n^{2}} \sum_{r=1}^{n} \sum_{t=1}^{n} d_{r t}^{2}=\frac{2}{n} \sum_{r=1}^{n} x_{r}^{t} x_{r}
\end{aligned}
$$

Disubtitusi ke dalam persamaan (2.3) menjadi : $b_{r t}=x_{r}^{T} x_{t}=-\frac{1}{2}\left(d_{r t}^{2}-\frac{1}{n} \sum_{r=1}^{n} d_{r t}^{2}=\frac{1}{n} \sum_{s=1}^{n} d_{r t}^{2}+\frac{1}{n^{2}}\right.$ $\left.\sum_{r=1}^{n} \sum_{t=1}^{n} d_{r t}^{2}\right)$

$$
=a_{r t}-a_{r}-a_{t}+a
$$

Matriks hasil kali dalam B dapat juga diekspresikan sebagai $B=X X^{T}$, dimana $\mathrm{X}=\left(x_{1}, \ldots, x_{n}\right)^{T}$ adalah matriks 
koordinat berukuran $n \times p$. secara singkat algoritma classical scalling sebagai berikut :

1. Mencari matriks B $\left[a_{r t}-a_{r}-a_{t}+a\right]$

2. Mencari akar ciri $\lambda_{1}, \ldots, \lambda_{n-1}$ dan vector ciri $v_{1}, \ldots, v_{n-1}$ yang kemudian dinormalkan sehingga $v_{i}^{t} v_{1}=\lambda_{1}$

3. Menetukan koordinat $n$ titik pada ruang euklid dimensi $p$ dengan $x_{r i}=v_{i r}(1, \ldots, n ; i=1, \ldots, p$.

b. Multidimensional scalling Non-Metrik

Multidimensional scaling non-metrik menunjukan bahwa skala pengukuran datanya nominal atau ordinal. Data jarak yang digunakan dalam Multidimensional Scalling non-metrik adalah data yang dianggap bertipe ordinal [8].

Program MDS non-metrik menggunakan transformasi monoton ke data yang sebenarnya sehingga dapat dilakukan operasi aritmatika terhadap nilai ketidaksamaanya. MDS non-metrik sehingga menghasilkan konfigurasi dari objek-objek yang terdapat pada dimensi tertentu dan kemudian agar jarak antara objek sedekat mungkin dengan input nilai ketidaksamaan atau kesamaannya. Koordinat awal dari setiap subjek dapat diperoleh melalui cara yang sama seperti metode MDS metrik dengan asumsi bahwa meski data bukan jarak informasi yang sebenarnya tapi nilai urutan tersebut dipandang sebagai variabel interval [9].

Perbedaan utama dari model MDS adalah skala, skala yang di asumsikan oleh model untuk proximity. MDS yang paling popular digunakan adalah MDS nonmetrik. Karena itu, MDS non adalah menghasilkan Konfigurasi Dimensional $X$ sehingga jarak di atas $X$ disampaikan semaksimal mungkin sebagai proximity.

Perbedaan penting antara dua bentuk hasil MDS non-metrik dari bagaimana ini memperlakukan ikatan (nilai data yang sama). Solusi MDS, yaitu proximity yang sama tidak perlu dipetakan menjadi sama jarak. Pendekatan sekunder untuk ikatan (" menjaga hubungan tetap terikat”) mengarah pada persyaratan tambahan untuk MDS non-metrik, yaitu :

$$
f: p_{i j}=p_{k l} \rightarrow d_{i j}(X)=d_{k l}(X)
$$

kelemahan dari MDS non-metrik adalah memerlukan data pada tingkat skala yang lebih tinggi. Selain itu, MDS non-metrik biasanya mengarah pada solusi yang kurang sesuai dengan data, karena umumnya lebih sulit untuk mempersentasikan data yang lebih banyak model yang bersifat membatasi.

\section{Perbedaan MDS Metrik dan MDS Non-Metrik}

Perbedaan utama dari model MDS adalah skala, skala yang asumsikan oleh model untuk proximity. Model MDS yang paling popular dalam publikasi penelitian menggunakan MDS adalah MDS non-metrik. MDS non-metrik dibangun berdasarkan premis bahwa proximity $P_{j i}$ pada skla ordinal. Karena itu MDS nonmetrik adalah menghasilkan konfigurasi dimensional $X$ sehingga jarak di atas $X$ disampaikan semaksimal mungkin sebagai proximity. Urutan peringkat jarak harus secara optimal sesuai dengan peringkatnya urutan data. Di MDS non-metrik, fungsinya ,

$$
F: P_{j i} \rightarrow d_{j i}(\mathrm{X})
$$

Sehingga nilai monotonnya

$$
F: P_{j i}<P_{k l} \rightarrow d_{i j}(X) \leq d_{k l}(X)
$$

dimana untuk semua pasangan $i$ dan $j, k$ dan $I$, masingmasing untuk data (diasumsikan disini menjadi ketidaksamaan) diberikan. Proximity yang tidak didefinisikan (" missing data") adalah dilompati oleh formula ini. Artinya, jika $P_{j i}$ hilang, itu tidak membtasi solusi MDS sehingga jarak $d_{j i}(X)$ bisa dipilih semenamena.

Pendekatan sekunder untuk ikatan ("menjaga hubungan tetap terikat") mengarah pada persyaratan tambahan untuk MDS non-metrik, yaitu :

$$
F: P_{j i}=P_{k l} \rightarrow d_{i j}(X)=d_{k l}(X)
$$

pendekatan untuk hubungan biasanya lebih bermakna dalam hal data. Kelemahan dari MDS non-metrik adalah memerlukan data pada tingkat skala yang lebih tinggi. Selain itu, MDS non-metrik biasnya mengarah pada solusi yang kurang sesuai dengan data, karena umumnya lebih sulit untuk mempresentasikan data yang lebih banyak model yang bersifat membatasi.

Model standar MDS metrik, dimana :

$$
P_{j i} \rightarrow \mathrm{a}+\mathrm{b} * P_{j i}=d_{j i}(X)
$$

MDS metrik dapat mempertahankan data secara linear pada jarak jauh, ini masuk akal hanya jika data diambil sebagai skala interval, artinya diasumsiskan tidak ada artinya informasi data hilang jika diskalakan dan dikaliakan dengan cara yang berubah-ubah $b$ konstan ( kecuali $\mathrm{b}=0$ ) atau dengan menambahkan konstanta apapun pada seiap nilai data. Semua pernyataan tentang data yang tetap invariant dibawah transformasi linear semacam itu dianggap bermakna ; semua pernyataan lainnya (misalnya, pernyataan tentang rasio nilai data tertentu ) tidak berarti [10].

\section{Nilai Stress (standardized Residual Sum of Square) Dalam MDS}

Tingkat kesesuaian model (goodness off fit) menggunakan ukuran kriteria kesalahan (lack of fit or error) STRESS. Program ASCAL mengandung proses iterasi terdiri dari dua langkah utama yakni mengubah data berupa jarak antara pasangan objek menjadi ukuran baru yang disebut disparities dan menduga koordinat setiap objek berdasarkan jarak dan disparities [11][12].

$$
\text { Stress }=\sqrt{\frac{\sum_{i<j}^{n}\left(d_{i j}-\hat{d}_{i j}\right)^{2}}{\sum_{i<j}^{n} d_{i j}^{2}}}
$$

dimana $d_{i j}$ adalah jarak antara objek ke-i dan objek ke-j dan $\hat{d}_{i j}=$ disparities antara objek ke-i dan objek ke-j. Semakin kecil nilai Stress menunjukan bahwa hubungan monoton yang terbentuk antara ketidaksamaan dengan disparities semakin baik (didapat kesesuaian) dan kriteria peta persepsi (perceptual map) yang terbentuk semakin sempurna.

Tabel 2. NIlai Stress dan kondisi yang dibentuk

\begin{tabular}{|c|c|}
\hline STRESS\% & (goodness offit) \\
\hline$>20 \%$ & Buruk \\
\hline $20-10 \%$ & Cukup \\
\hline $10-5 \%$ & Baik \\
\hline $5-2,5 \%$ & Sangat baik \\
\hline$<2,5 \%$ & Sempurna \\
\hline
\end{tabular}


Apakah dengan meningkatkan dimensi sebuah solusi MDS akan mengarah pada nilai Stress "secara signifikan" lebih kecil. Untuk menjawab pertanyaan ini, yang dapat dilakukan pertama yaitu menghitung solusi MDS, katakanlah, 1-,2-,3-, dang ruang berdimensi lebih tinggi kemudian memeriksa bagaimana nilai stress menurunkan saat dimensi dari solusi MDS meningkat. Salah satu cara untuk mengevaluasi nilai-nilai ini adalah membandingkannya dengan nilai stress untuk data acak mencari siku dalam penurunan stress versus fungsi dimensi, sama dengan analisis faktor [10]

\section{METODE PENELITIAN}

WAKTU DAN TEMPAT PENELITIAN

Penelitian ini akan dilakukan di RSUD Teep Amurang pada bulan Juli - Agustus tahun 2019. Penelitian ini menggunakan data primer yang diperoleh dengan pembagian kuesioner. Responden dalam penelitian ini yaitu pasien yang mendapatkan pelayanan di RSUD Teep Amurang yaitu Pasien Rawat inap dan rawat jalan. Responden dalam penelitian ini adalah 41 responden yang mendapatkan pelayanan di RSUD.

\section{JENIS DATA DAN SUMBER DATA}

Penelitian ini bersifat deskriptif yang menggambarkan tingkat kepuasan pasien terhadap pelayanan di RSUD Teep Amurang. Sumber data yang digunakan yaitu : data kunjungan pasien rawat inap di RSUD Teep Amurang.

\section{HASIL DAN PEMBAHASAN \\ Analisis Deskriptif}

Analisis deskriptif adalah suatu metode penyajian segugus data untuk memberikan informasi yang berguna sehingga mengarah pada penjelasan dan penafsiran [13].

\section{Pernyataan Tangibles (Berwujud)}

Pada umumnya Tangibles (Berwujud) adalah hal yang sangat penting yang diperlukan dalam Rumah Sakit. Apakah instalasi Rumah Sakit tersebut sudah memiliki pelayanan yang nyata yang disedikan dalam Rumah Sakit. Hal ini dapat dilihat pada nilai yang diperoleh dari responden pasien, seperti pada gambar di bawah ini :

\section{Pernyataan A1-A4}

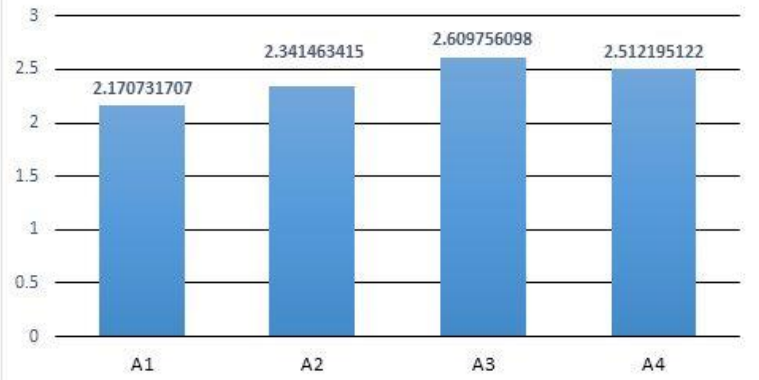

Gambar 1. Karakteristik Persepsi Responden Pasien Terhadap Pernyataan Tangibles (Berwujud) A1-A4

Dalam gambar 1 responden cendurung belum puas untuk pelayanan Rumah Sakit pada pernyataan A1-A2. Nilai yang tertinngi berada pada pernyataan A3 sebesar 2.6097. Yang berarti dalam hal ini Intalasi Rumah Sakit harus lebih ditingkatkan baik kualitas pelayanan dan ketersedian perlengkapan Rumah Sakit baik dalam persedian obat-obatan maupun tentang kebersihan dan kerapihan Rumah Sakit.

Dalam pelayanan Rumah Sakit juga harus mempunyai sifat dan kemampuan untuk memberikan perhatian penuh kepada pasien, kemudahan melakukan kontak dan komunikasi yang baik. Berikut adalah hasil penilaian pasien.

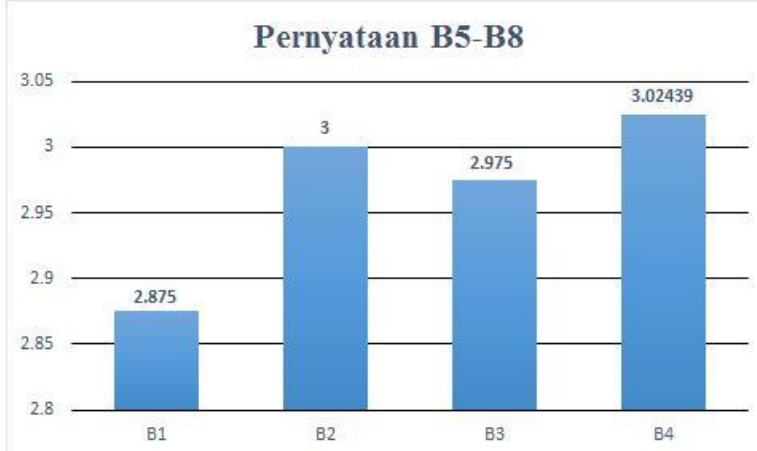

Gambar 2. Karakteristik Persepsi Responden Pasien terhadap Emphaty (Empati) B5-B8

Pada gambar 2, untuk penilaian terhadap Empati responden puas terhadap pelayanan yang diberikan. Bisa dilihat pada gambar untuk pernyataan B6 dan B8 banyak responden yang puas terhadap pelayanan intalasi Rumah Sakit terhadap empati petugas di instalasi karena mampu memberikan pelayanan yang baik dan petugas RSD bisa berkomunikasi dengan baik kepada pasien. Nilai yang tertinggi berada pada pernyataan B4 sebesar 3.0243. Sedangkan nilai yang terendah berada pada pernyataan B1 sebesar 2.875 .

Dalam Pelayanan rumah sakit bukan hanya sikap empati yang bisa dinilai terdapat juga penilaian terhadap Reliability (Keandalan) petugas dalam melayani pasien dengan cepat dan mampu menangani dan tanggap terhadap keluhan pasien. Berikut gambar terhadap Reliability (kendalan).

Pernyataan C9-C11

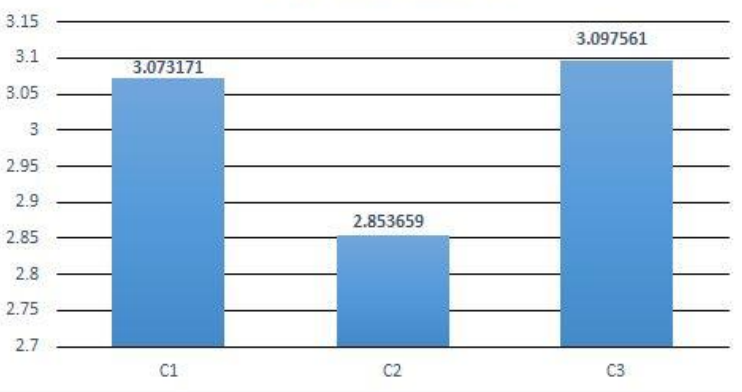

Gambar 3. Karakteristik Persepsi Responden Pasien terhadap Reliability (Keandalan) C9-C11

Berdasarkan gambar 3, bisa dilihat untuk pernyataan $\mathrm{C}-10$ ada beberapa responden yang belum puas terhadap terhadap kecepatan pelayanan dalam menangani permintaan pasien. Untuk pernyataan $\mathrm{C}-11$ responden sangat puas dalam ketanggapan petugas menangani keluhan pasien karena berada pada nilai yang tertinggi sebesar 3.0975. Dalam hal ini untuk pernyataan $\mathrm{C} 9-\mathrm{C} 11$ responden puas.

Responsiveness (ketanggapan atau kepedulian) yaitu kemampuan untuk membantu konsumen dan 
meningkatkan kecepatan pelayanan. Berikut hasil penilaian tersebut.

\section{Pernyataan D12-D14}

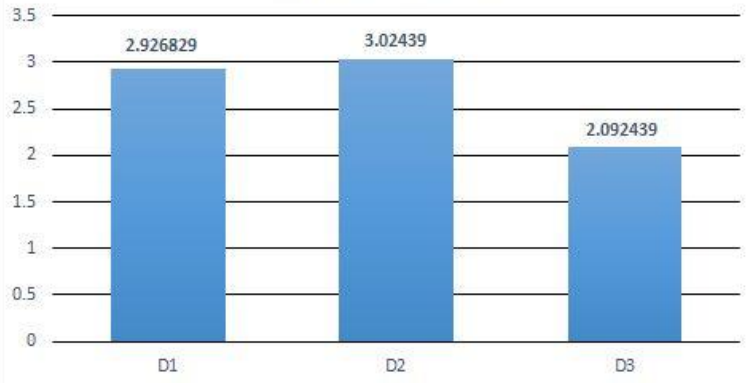

Gambar 4. Karakteristik Persepsi Responden Pasien terhadap Responsivenesss (Ketanggapan) D12-D14.

Pada gambar 4, kepuasan responden yang lebih banyak berada pada pernyataan D2 sebesar 3.02439. Sedangkan untuk pernyataan D12 dan D14 ada responden yang belum terlalu puas terhadap pelayanan RSUD dalam memberikan informasi pelayanan pro aktif oleh petugas. Untuk D12 sebesar 2.926829 dan untuk D14 sebesar 2.092439. Tetapi secara keseluruhan responden sudah puas dalam pelayanan RSUD.

Selain harus memilki ketanggapan pelayanan rumah sakit harus memiliki Assurance (Jaminan) terhadap pasien. kompetensi yang dimiliki sehingga memberikan rasa aman, bebas dari bahaya, risiko atau keraguan dan kepastian yang mencakup pengetahuan, perilaku dan sifat yang dapat dipercaya.

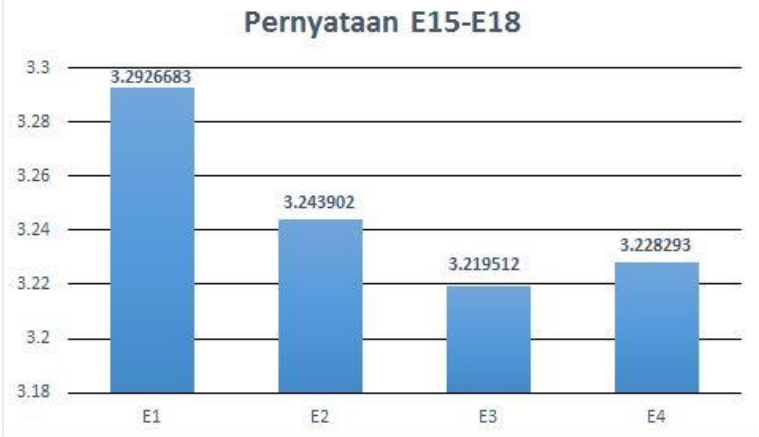

Gambar 5. Karakteristik Persepsi Responden Pasien terhadap Assurance (Jaminan) E15-E18

Pada gambar 5, untuk pernytaan E15-E18 responden sudah puasa dalam pelayanan RSUD terhadap Jaminan dalam RSUD yang tersedia. Untuk nilai tertinggi berada pada pernyataan E15 sebesar 3.2926. Responden puas terhadap pelayanan RSUD dalam memberikan obat sesuai resep dan kebutuhan pasien.

\section{Hasil Pengujian Validitas dan Reliabilitas}

Setelah melakukan penyebaran kueisioner, peneliti melakukan pengujian hasil kueisioner dengan uji validitas dan uji reliabilitas. Uji validitas dilakukan untuk mengetahui sejauh mana pertanyaan-pertanyaan yang diajukan dapat mewakili objek yang diamati, sedangkan uji reliabilitas dilakukan untuk mengetahui konsistensi atau keteraturan hasil pengukuran suatu instrument apabila instrument tersebut digunakan lagi sebagai alat ukur suatu objek atau responden [14].
Uji kuesioner ini dilakukan terhadap 20 orang responden pasien RSUD Teep Amurang. Berikut adalah hasil uji validitas sebanyak 20 responden untuk setiap pernyataan yang ada pada kueisioner.

Tabel 3.Hasil Uji Validitas Pernyataan Tangibles (Berwujud)

\begin{tabular}{|c|c|c|c|}
\hline No Soal & $\mathbf{r}$ hitung & $\mathbf{r}$ tabel & Keterangan \\
\hline $\mathbf{A 1}$ & 0.585 & 0.5425 & Valid \\
\hline $\mathbf{A 2}$ & 0.803 & 0.5425 & Valid \\
\hline $\mathbf{A 3}$ & 0.880 & 0.5425 & Valid \\
\hline $\mathbf{A 4}$ & 0.733 & 0.5425 & Valid \\
\hline
\end{tabular}

Tabel 3, adalah hasil uji validitas yang menyatakan bahwa 4 atribut yang di uji dari pernyataan tangibles, semuanya dinyatakan valid karena nilai $r$ hitung $>r$ tabel. Hasil uji reliabilitas ini menghasilkan nilai Cronbach's Alpha lebih besar dari 0,65 yaitu 0,900 sehingga dapat disimpulkan atribut-atribut dalam pernyataan ini reliabel.

Tabel 4. Hasil Uji Validitas Pernyataan Emphaty (Empati)

\begin{tabular}{|c|c|c|c|}
\hline No Soal & r hitung & r tabel & Keterangan \\
\hline B1 & 0.849 & 0.5425 & Valid \\
\hline B2 & 0.890 & 0.5425 & Valid \\
\hline B3 & 0.860 & 0.5425 & Valid \\
\hline B4 & 0.830 & 0.5425 & Valid \\
\hline
\end{tabular}

Tabel 4, adalah hasil uji validitas yang menyatakan bahwa 4 atribut yang di uji dari pernyataan emphaty, semuanya dinyatakan valid karena nilai $r$ hitung $>r$ tabel. Hasil uji reliabilitas ini dengan nilai Cronbach's Alpha sebesar o,820 lebih besar dari o,65, maka peryataan tersebut dinyatakan telah reliabel.

Tabel 5. Hasil Uji Validitas Pernyataan Reability (Keandalan)

\begin{tabular}{|c|c|c|c|}
\hline No Soal & r hitung & r tabel & Keterangan \\
\hline C1 & 0.851 & 0.5425 & Valid \\
\hline C2 & 0.745 & 0.5425 & Valid \\
\hline C3 & 0.881 & 0.5425 & Valid \\
\hline
\end{tabular}

Tabel 5, adalah hasil uji validitas yang menyatakan bahwa 4 atribut yang di uji dari pernyataan reability, semuanya dinyatakan valid karena nilai $r_{\text {hitung }}$ $>r$ tabel. Uji reliabilitas untuk pernyataan tersebut diperoleh nilai Cronbach's Alpha 0,780 yang lebih besar dari 0,65 , maka peryataan tersebut dinyatakan telah reliabel. 
Tabel 6. Hasil Uji Validitas Pernyataan Responsiveness (Ketanggapan)

\begin{tabular}{|c|c|c|c|}
\hline No Soal & r hitung & r tabel & Keterangan \\
\hline D1 & 0.922 & 0.5425 & Valid \\
\hline D2 & 0.819 & 0.5425 & Valid \\
\hline D3 & 0,922 & 0.5425 & Valid \\
\hline
\end{tabular}

Tabel 6, adalah hasil uji validitas yang menyatakan bahwa 4 atribut yang di uji dari pernyataan responsiveness, semuanya dinyatakan valid karena nilai $r_{\text {hitung }}>r_{\text {tabel. }}$ nilai uji reliabilitas untuk pernyataan tersebut untuk nilai Cronbach's Alpha sebesar 0,899 yang lebih besar dari nilai 0,65 , maka pernyataan ini dinyatakan telah reliabel.

Tabel 7. Uji Validitas Pernyataan Assurance (Jaminan)

\begin{tabular}{|c|c|c|c|}
\hline No Soal & r hitung & r tabel & Keterangan \\
\hline E1 & 0.856 & 0.5425 & Valid \\
\hline E2 & 0.908 & 0.5425 & Valid \\
\hline E3 & 0.718 & 0.5425 & Valid \\
\hline E4 & 0.913 & 0.5425 & Valid \\
\hline
\end{tabular}

Tabel 7, adalah hasil uji validitas yang menyatakan bahwa 4 atribut yang di uji dari pernyataan assurance, semuanya dinyatakan valid karena nilai $r$ hitung $>r$ tabel. uji reliability menghasilkan nilai Cronbach's Alpha 0,849 lebih besar dari nilai o,65, maka pernyataan tersebut dinyakan reliabel.

\section{Analisis Multidimensional Scaling (MDS)}

Hasil dari pengolahan program MDS ini didapat matriks jarak dengan jarak Euclid yang ditunjukan pada gambar dibawah ini :

\begin{tabular}{|llllll|}
\hline & 1 & \multicolumn{1}{l}{ 2 } & 3 & 4 & \multicolumn{1}{l|}{5} \\
& & & & & \\
1 & .000 & & & & \\
2 & 2.776 & .000 & & & \\
3 & 2.766 & .456 & .000 & & \\
4 & 3.071 & .456 & .456 & .000 & \\
5 & 3.747 & 1.737 & 1.718 & 2.140 & .000 \\
& & & & & \\
\hline
\end{tabular}

Gambar 6. Output jarak euclid dari 5 (lima) Pernyataan

Pada gambar 6, adalah hasil jarak Euclid dari 5 pernyataan dengan menggunakan bantuan software SPSS, data jarak ini juga diperoleh titik-titik koordinat stimulus yang kemudian menunjukan letak posisi antara 5 pernyataan tersebut. Hasil plot koordinat stimulus dua dimensi yang diperoleh adalah sebagai berikut :

Gambar 7 dibawah ini adalah stimulus koordinat dimensi 1 dan 2, yang akan digunakan untuk menentukan posisi setiap pernyataan responden pasien RSUD Teep Amurang yang dalam konfigurasi ruang dua dimensi.

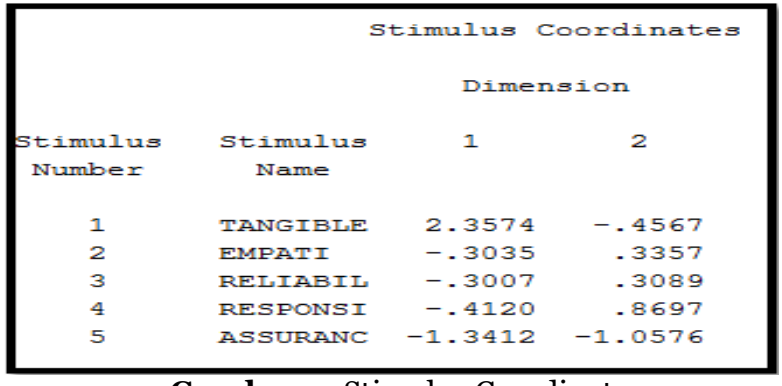

Gambar 7. Stimulus Coordinat

\section{Hasil Nilai Stress (Standardized Risidual Sum of Square)}

Dalam menentukan kesesuaian dalam analisis multidimensional scaling, diperoleh dari nilai stress, semakin rendah nilai stress maka semakin baik model multidimensional scaling yang dihasilkan. Hasil dari nilai stress dapat dilihat pada gambar 8 di bawah ini

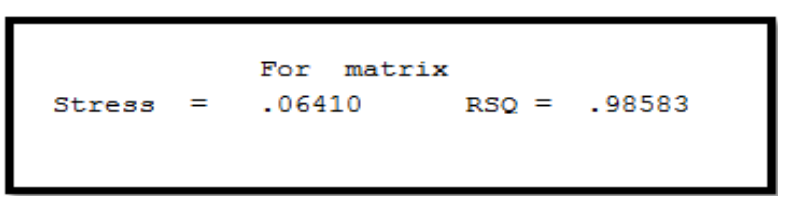

Gambar 8. Output Nilai Stress

Hasil output pada nilai stress diperoleh sebesar o.06410 yang berarti model MDS ini cukup baik, untuk tingkat kesesuaian model. Didukung dengan nilai RSQ yang hasilnya sebesar 0.98583 , berarti model MDS cukup pada data yang digunakan dalam dua dimensi.

Berikut adalah peta hasil ALSCAL untuk menampilkan plot MDS dari hasil penelitian terhadap penilaian responden terhadap Tangibles, Empati, Reliability, Responsiveness, Assurance pada RSUD Teep Amurang.

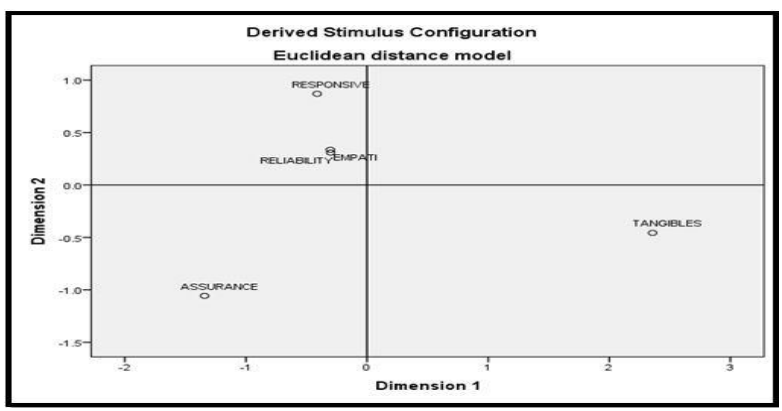

Gambar 9, menunjukan posisi dari 5 pernyataan kepuasan pasien berdasarkan jumlah sarana kesehatan yang ada pada RSUD Teep Amurang pada tahun 2019.

Pada gambar 9 terlihat secara keseluruhan terdapat tiga kelompok yang memiliki kemiripan. Ketiga kelompok tersebut adalah :

- Responsivennes

- Reliability

- Empati

Kecuali dengan pernyataan Assurance yang berada pada kuadran III tersendiri dengan posisi berada pada dimensi 1 sebelah kiri (negative) dan berada pada dimensi 2 bagian bawah (negatif) yang artiya bahwa kepuasan pasien pada pernyataan Assurance pada RSUD Teep Amurang dikatakan masih kurang.Yang artinya pelayanan bagian Assurance perlu di tingkatkan lagi, sedangkan untuk pernyataan Tangibles yang berada pada kuadran IV (kanan bawah) 
yang berada pada dimensi I sebelah kanan (positif) dengan posisi dimensi 2 kanan bawah (negative) yang artinya pelayanan bagian Tangibles cukup baik.

\section{Penutup \\ Kesimpulan}

Berdasarkan hasil dan pembahasan yang diperoleh maka dapat disimpulkan bahwa:

1. Sesuai dengan penilaian responden, untuk $\mathrm{A}_{3}$ (Instalasi farmasi RSUD memiliki ruang tunggu yang nyaman), B8 (Penampilan karyawan atau pegawai di instalasi farmasi RSUD rapih dan bersih), C11 (Petugas di instalasi farmasi RSUD tanggap menangani keluhan pasien), D13 (Pasien mendapatkan pelayanan secara pro-aktif oleh petugas di instalasi farmasi RSUD),dan E15 (Petugas di instalasi farmasi RSUD tepat memberikan obat sesuai kebutuhan pasien). Mempunyai keunggulan penilaian yang tinggi yang berarti responden puas.

2. Sedangkan pada A1 (Instalasi Farmasi RSUD sudah memiliki obat yang lengkap), B5 (Pelayanan yang diberikan di Intalasi Farmasi RSUD kepada pasien tanpa memandang status sosial), C10 (Petugas di Instalasi Farmasi RSUD cepat melayani permintaan medis), D3 (Petugas di Instalasi Farmasi RSUD dapat memberikan saran yang bijaksana), dan E17 (Petugas di Intalasi Farmasi RSUD memberikan informasi tentang cara pemakaian obat). Merupakan penilaian terendah yang berari ada beberapa responden yang belum terlalu puas dalam pelayanan RSUD.

3. Pada hasil analisis Multidimensional Scalling (MDS) bahwa pada kuadran 1 terdapat Emphaty, Reliability, Responsiveness berada pada kuadran yang sama, dengan nilai kemiripan yang sama berada pada Reliability dan Emphaty.

\section{REFERENSI}

[1] Aryani F. Husnawati., Muharni S., Liasari M., Afrianti R. 2015. Analisa Kepuasan Pasien Rawat Jalan Terhadap Kualitas Pelayanan Di Instalasi Farmasi Rumah Sakit Islam Ibnu Sina Pekanbaru. Sekolah Tinggi Farmasi Riau.

[2] Kotler, P. 2011. Manajemen pemasaran di Indonesia; Analisis, perencanaan, Implementasi dan pengendalian. Jakarta : Salempa Empat.

[3] Parasuraman, A, Zeithaml, V.A.and Berry, L.L 1998, SERVQUAL : a multiple Itm scale for Measuring consumer prepceptions of service quality, Journal of Retling, vol.64 No,1,pp.12-40

[4] Bilson Simamora. 2005. Analisis Multivariat Pemasaran. Jakarta : Gramedia Pustaka Utama.

[5] Pura, M. H, Komalig, dan Nelson, N. 2012. Analisis Multidimensional Scalling Untuk Jarak Atara Fakultas-Fakultas serta Program Pasca Sarjana di Universitas Sam Ratulangi Manado. D'Cartesian : Jurnal Matematika dan Aplikasi, Vol. 8,No.1 (Maret 2019) :65-68.

[6] Timm, N. H. 2002. Applied Multivariate Analysis.Springer-Verleg. New York
[7] Ginanjar, I. 2008. Aplikasi Multidimensional Scaling (MDS) untuk Peningkatan Pelayanan Proses Belajar Mengajar (PBM). Staf Jurusan Statistika FMIPA UNPAD

[8] Matijik, A.A, dan Sumertajaya, I.M.,2011. Sidik Peubah Ganda. Kampus IPB Darmaga,Bogor.

[9] Walundungo, G. A. M, Paendong, dan Tohap, M. 2009. Penggunaan Analisis Multidimensional Scaling untuk Mengetahui Kemiripan Rumah Makan di Manado Town Square Berdasarkan Karakteristik Pelanggan. Jurnal MIPA Unsrat Online. 3(1):1-6.

[10] Borg, W R \& Gall, M D. 2003. Educational Research : an Introduction (7.ed). New York; Longman. Inc

[11] Morrison, D.F,2005. Multivariate Statistical Methods, $4^{\text {th }}$ Ed, Thomson Learning Inc, Singapore.

[12] Sihombing, I, D, 2016. Laporan Hasil Penelitian Analisis Multivariat dengan Metode Multidimensional Scalling Untuk Peningkatan Proses Mengajar (PMB) Di FKIP UHN Medan. Lembaga Penelitian Universitas HKBP Medan.

[13] Aunuddin, 1998; Analisis Data; IPB Press, Bogor

[14] Martini, Eris. 2015. Analisi Positioning Program Studi Matematika FST berdasarkan Minat Mahasiswa UIN Syarif Hidayatullah Jakarta. Program Studi Matematika Fakultas Sains dan Teknologi. Universitas Islam Negeri Syarif Hidayatullah Jakarta

\section{Liani Somba (lianisomba97@gmail.com)}

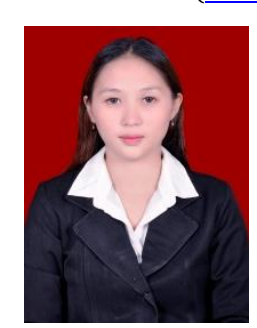
Lahir di Manado, Sulawesi Utara pada tanggal 15 Agustus 1997. Menempuh pendidikan tinggi Jurusan Matematika, FMIPA, Universitas Sam Ratulangi Manado. Tahun 2019 adalah tahun terakhir ia menempuh studi. Makalah ini merupakan hasil penelitian skripsinya yang

dipublikasikan.

Nelson Nainggolan (n-nelson@unsrat.ac.id)

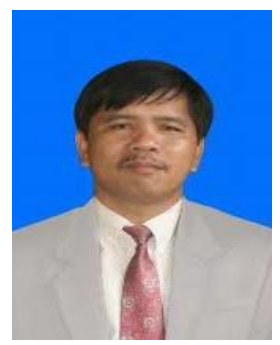

Lahir di Tapanuli Utara tanggal 9 Maret 1967. Gelar sarjana pendidikan Matematika diperoleh tahun 1992 di FMIPA IKIP Negeri Medan. Tahun 1996 menyelesaikan studi S2, di jurusan Matematika ITB Bandung. Tahun 2011 menyelesaikan studi S3 pada bidang Matematika di Universitas Padjadjaran Bandung.

Saat ini menjadi pengajar akademik tetap di jurusan Matematika FMIPA Unsrat Manado.

\section{Hanny Komalig (hanoyo7@yahoo.com)}

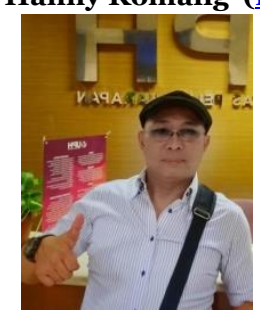

Lahir di Manado tanggal 6 Maret 1968.Pada tahun 1991 mendapatkan Gelar sarjana sains (S.Si) yang diperoleh dari Universitas Sam Ratulangi Manado. Gelar Master Sains (M.Si) di Institut Pertanian Bogor pad tahun 1999. Ia sebagai Pengajar tetap di UNSAT. 